\title{
Adapting Public Sector Services to Local Delivery
}

\section{Ishrat Husain*}

\begin{abstract}
This article describes the local government system established in the 2001 Devolution Plan and its evolution over the period 2002-07, with a focus on two essential public services, education and health. We believe that the devolution of service delivery functions, delegation of financial powers, decentralization of authority, and deconcentration of executive powers, can, together, lead to better accountability of results and, hence, to improved public service delivery to the poor and marginalized. The Devolution Plan made inroads toward these goals, particularly in education, but their achievement was incomplete due to a number of factors, among those incomplete fiscal decentralization, limited targeting of backward areas, and centralizing tendencies of the provincial departments and civil service. Recommendations are offered on how to further develop the local government system more generally, with an eye towards increasing accountability and improving coordination both across local governments and between tiers. For this, complementary reforms to simplify business processes and revamp human resource management policies are needed; introducing a district level civil service is among the suggested changes. The article concludes with detailed recommendations on improving the decentralized delivery of education and health services.
\end{abstract}

Keywords: Devolution, decentralization, service delivery, health, education.

JEL classification: H75.

\section{Introduction}

Studies have investigated the economic growth-poverty nexus across time and across countries over the last five decades. It is now fairly clear that, while growth is necessary to alleviate poverty, it is not sufficient. Human development and access to social services in a well functioning governance structure distribute the benefits of growth more equitably and helps lift people out of poverty.

\footnotetext{
* Dean and Director, Institute of Business Administration (IBA), Karachi.
} 
The extent to which the state is successfully able to deliver services across a large spectrum of the population is a function of its tradition, history, mandate, and capability. In Pakistan, the social contract between the state and society as defined in the constitution makes the government responsible for providing education and health to the population. The recent $18^{\text {th }}$ Amendment to the constitution has gone a step further and deemed the right to education a fundamental human right of Pakistani citizens.

The empirical literature shows a strong, unconditional, and positive relationship between decentralization and accountability. Bardhan and Mookherjee (2007) suggest that electoral decentralization and the devolution of public service provision complement pro-poor governance reforms in developing countries. The World Bank's World Development Report (2004) argues that the accountability of governments to local communities and marginalized social groups will increase by assigning service delivery functions to politicians who are closer to the people and by making the former electorally accountable. At the micro-level Cheema and Mohmand (2006) analyzed a dataset of 364 households in the rural tehsil (administrative unit) of Jaranwala in Faisalabad district to identify what types of households gain and lose as a result of electoral decentralization and whether the change in post-reform provision between different household types has become equitable. The empirical results of their study show that increased access to development funds and expanded mandates for union nazims (mayors) have significantly increased union-level service provision within a short period. However, the villages to which the nazims belong have enjoyed a relatively substantial increase compared to nonnazim villages. The study also finds that the increase in post-reform provision in nazim villages is less elite-based because it encompasses small peasants, minority peasant biraderis (clans), and nonagricultural castes.

Governments have found a range of methods for delivering these services. The World Bank (2004) catalogues successful examples ranging from direct provision by the government and contracting out to the private sector and nongovernment organizations (NGOs), to decentralization to local governments, community participation, and direct transfers to households. Both the successes and failures of these experiments provide some useful lessons.

First, accountability needs to be strengthened between the poor and service providers, between the poor and government institutions, and between government institutions and service providers. Second, it is 
necessary to expand poor people's choices and participation in service delivery. Thus, children from poor households should not have to remain limited to substandard instruction at state-run schools when they can be provided financial means by the government to pursue their education at private schools of their choice. The same applies to health clinics and hospitals. Mexico and Brazil have lifted millions out of poverty by making cash transfers to poor households conditional on their education, immunization, vaccination, etc.

Third, it is not the availability of financial resources that alone makes the differences to outcomes. Studies have shown that, of the central government's budget allocation for running a school, the actual amount that reaches the school after passing through various government channels is only a tenth of the original allocation. Exclusive preoccupation with expenditures on education and health while ignoring the myriad problems of the governance of these sectors at all levels is palpably wrong. Reforms in the governance structure of the public sector and regulation of the nongovernment sector will have a much stronger impact on the quality of these services and on access to them by the poor.

There is no doubt that the government is responsible for people's health and education - these are considered fundamental human rightsbut the distinction between its different roles-financier, provider, regulator, policymaker, and planner-should always be kept in mind. Financing responsibilities, whether direct or indirect, should be vested in the government, as should regulatory and planning functions. Separating the roles of policymaker and provider, however, is not always easy. Teachers' unions, health professionals' alliances, and others who benefit from state patronage may attempt to block such efforts. In the delivery of services, the government could invoke the assistance and collaboration of other segments of society that have the requisite expertise and competence but not necessarily the financial means to scale up, such as communities, organizations, NGOs, and the private sector. The state-provider relationship in delivering services can be strengthened if the policymaker is successful in drawing up and enforcing contracts with the providers and monitoring their performance.

In cases where the government takes it upon itself to deliver these services directly, studies show that improving the efficiency of that spending is key to reaping substantial benefits. On average, the relationship between public spending on health and education and its outcomes is weak or inconsistent (see World Bank, 2004). Most public 
spending on health and education goes to the nonpoor. Government departments construct school buildings at exorbitant costs. Teachers are hired but nepotism, corruption, leakages, weak supervision, and lack of accountability do not allow effective delivery of education to the intended beneficiaries. Both anecdotal evidence and surveys of primary healthcare and educational facilities have consistently pointed to high absentee rates among doctors and teachers. In contrast, examples from nongovernment schools and clinics tend to show teachers and health workers delivering timely, efficient, and courteous services, often in difficult circumstances, and drawing far less monetary and fringe benefits compared to their counterparts in government-run institutions.

For direct delivery by the government, the transfer of responsibility for these services to lower tiers of government improves access by the poor (Devolution Trust for Community Empowerment, 2011). Local government management of schools and hospitals and demand-side subsidies to poor households under monitoring and oversight by the government results in favorable education and health outcomes.

This article focuses on two essential public services, education and health, which are both closely correlated with poverty reduction. A review of other services such as water supply and sanitation, nutrition, social protection, and social safety nets such as the Bait-ul-Mal, Benazir Income Support Program, zakat funds, and private philanthropy, would form an independent study and is, therefore, not attempted here. Progress with respect to skills development, guaranteed rural employment, and works programs in recent years has been insignificant. Microfinance has begun to make a difference to poverty alleviation but does not qualify as a public service.

In light of the empirical evidence, our main argument is that the devolution of service delivery functions, delegation of financial powers, decentralization of authority, and deconcentration of executive powers, can, together, lead to better accountability of results and, hence, to improved public service delivery to the poor and marginalized. Even if the underlying patron-client relationship persists, there will still be wider scope for including clients who were traditionally denied access under a parliamentary member-centered system. The representation of marginalized groups, such as women, peasants, and labor, in electoral politics enhances their chances of improved access to services (Hasnain, 2010). 
Citizen participation mechanisms such as citizens' community boards (CCBs) and school councils can also prove powerful instruments for citizen empowerment. In light of this argument, it is regrettable that the 2001 Devolution Plan was prematurely and abruptly abandoned after the national elections in 2008 without any proper assessment of its advantages and disadvantages. No serious effort was made to retain and build on its strengths or to modify or remove its weaknesses. Unnecessary controversies have been initiated on points that have nothing to do with devolution itself. Accordingly, this article presents a balanced analysis of the strengths and weaknesses of the Devolution Plan, and a series of proposals to improve the local government system and delivery of social services.

\section{Why Local Government?}

Pakistan's constitution divides the responsibility for managing the affairs of the federation of Pakistan among three tiers of governmentfederal, provincial, and local. The $18^{\text {th }}$ Amendment to the constitution has transferred a number of subjects that were previously on the Concurrent List to the provinces. This devolution of powers from the federal government to the provinces was accompanied by the National Finance Commission (NFC) Award, which has substantially enhanced the provinces' share in the federal divisible pool.

At the same time as the provinces have been rightly strengthened, there has been a major setback to the local government system with the provinces' abolition of the structures created under the 2001 Devolution Plan. Many members of the national and provincial assemblies are opposed to strengthening local governments and are committed to diluting the administrative and financial powers of this third tier. The question that therefore arises is: What is the justification for a strong local government system?

First, local governments form an integral part of the democratic governance framework that allows greater participation by citizens in the management and control of their day-to-day affairs. Tradeoffs are calculated and priorities assigned among various development projects in a more realistic and pragmatic manner under local governments. Their intimate knowledge of local problems and solutions to resolve those problems lead to better outcomes and more efficient resource utilization than under a more centralized system of resource allocation. Decentralized decision making has proved to be the cornerstone of democratic 
governance. The benefit-cost analysis and, therefore, allocative efficiency are superior under a decentralized system.

Second, empirical evidence shows that raising taxes or charging user fees for services at a local level is easier-taxpayers can see the visible benefits of such payments whereas they may be reluctant to contribute to a remote central pot whose purpose is not known. With its low tax-to-GDP ratio, Pakistan could mobilize additional resources by raising provincial and local taxes in the form of an urban immovable property tax, capital gains tax, agriculture tax, and user fees and charges.

Third, the deprivation index shows that at least 80 districts in the country are deprived of basic services (Jamal, Khan, Toor, \& Amir, 2003). Pakistan's population has risen from 30 million in 1947 to 180 million today, making it impossible for such a large population to be served from Islamabad or the four provincial capitals. The peculiar circumstances and needs of each district require an understanding of its problems and the design of interventions that can address those problems. The criteria of backwardness and poverty should be given due weight in the distribution of resources out of the provincial divisible pool. Districts that are better-off or well endowed do not deserve a share of public resources that is proportionate to their population as their private incomes are reasonably high. Local-level public expenditures should be used to promote equity and welfare.

Fourth, access to basic services in Pakistan can be obtained either through money or by approaching elected representatives. Members of the national and provincial assemblies often remain absent from their constituencies and are not always easily accessible. Local government nazims and councilors, on the contrary, spend most of their time in their constituencies, and ordinary citizens can access them easily.

Access to services improved visibly after the 2001 local government system was implemented. Based on a survey carried out in 2005, Hasnain (2010) reports that, over 60 percent of the households sampled stated that they would approach a union councilor or nazim for help resolving their problems as compared to only 10 percent who said they would approach a provincial or national assembly member. This reflects the increase in accessibility of policymakers post-devolution. A system in which bureaucrats control the development departments provides neither access nor accountability for results. A system of elected nazims and councilors who remain responsive to citizens' needs is superior because they are liable 
to lose office if they do not fulfill their responsibilities and duties. The best one can do with a recalcitrant bureaucrat is to transfer him or her out of that district, which does not solve the inherent problem of access by the poor.

Fifth, the increased representation of the female population-a neglected segment of society-in the local government system had made participation more broad based. Women's political empowerment is the first step toward generating greater economic opportunity and contributing to economic uplift. Women councilors' interest in the social sectors meant that education, health, water, and sanitation received both more attention and resources. Pakistan has a very low female labor force participation rate, of which women's lack of political empowerment is a precursor.

\section{The 2001 Devolution Plan}

The 2001 Devolution Plan represented a major attempt to bring about fundamental structural changes in the local government apparatus and limit the bureaucracy's powers. Cheema, Khwaja, and Qadir (2005) describe the new system below:

Under devolution, a new elected government was created at the district level and politically linked to local governments at the sub-district level (tehsil and union council). The district government was headed by an elected nazim and the district administration head-the district coordination officer (DCO) reported directly to the elected head of the government. This was a significant departure from the previous system where the de facto head of the district administration, the deputy commissioner (DC), reported to the non-elected provincial secretariat. Moreover, the office of the DC has been abolished and the new head of district administration, the DCO is no longer the district magistrate and the district collector.

The union council (UC) was the directly elected tier of the local government. Nazims, naib nazims (deputy mayors), and union councilors were directly elected through adult franchise with reserved seats for women, minorities, laborers, and peasants. Each UC had, on average, a population of 20,000 under its jurisdiction and was thus closest to its citizens. Union nazims, naib nazims, and councilors constituted the electoral college that elected the district's nazims and naib nazims and the tehsil councils and councilors for the reserved seats. The next tier, i.e., the tehsil council 
consisted of union naib nazims as its ex-officio members while the district council comprised union nazims as its ex-officio members.

The elected government and provincial administration were integrated at the district and tehsil levels, the divisional tier was abolished altogether, and 12 departments of the provincial administration were devolved to the local level and made accountable to elected officials of the local government. Additionally, the vast majority of public services that had previously been under the provincial administration were transferred to local governments, substantially increasing the latter's responsibilities. Four districts were classified as city districts and entrusted with additional responsibilities for urban planning and municipal functions in the country's metropolitan areas. In all, the Devolution Plan created 107 district governments, 4 city district governments, 396 tehsil/town councils, and 6,125 union councils in the country.

Cheema and Mohmand (2006) focus on three types of changes brought about by the 2001 devolution: (i) changes in the decision-making level of the service, i.e., from provincial bureaucrats to district-level bureaucrats; (ii) changes in decision-makers' accountability, i.e., from bureaucrats to elected representatives at the district level; and (iii) changes in the fiscal resources available to the service.

Education departments, primary healthcare services, and the management of district and tehsil hospitals experienced the first type of change, where decisions that had previously been made by the provincial secretariat and provincial cabinet were now transferred to the district nazim and the executive district officers (EDOs). The municipal services provided by the provincial government's Local Government and Rural Development Department and its Public Health Engineering Department became the sole functional responsibility of the tehsil municipal administration (TMA). This was a fundamental shift because the power to allocate resources, prioritize projects, and deliver results moved away from 48 provincial departments to 6,000 local governments.

Under the second type of change, i.e., accountability-related change, the authors argue that, whereas prior to devolution, the deconcentrated provincial bureaucracy at the district level was accountable to their nonelected provincial secretariat, the 2001 devolution made it accountable to the elected heads of districts and tehsil governments. The de facto head of the district administration under the previous system, the DC - who reported to the nonelected commissioner under the previous system-now reported to the elected district nazim. 
Cheema and Mohmand (2006) also point out that the 2001 Devolution Plan established a "rule-based" fiscal transfer system between the provinces and local governments. Approximately 40 percent of the Provincial Consolidated Fund was distributed among local governments, and backwardness given due weight in order to ensure some form of equity across districts in the allocation of development funds. The other innovation was that these budgetary transfers did not lapse at the end of the year but were retained by the local governments concerned, which added to the flexibility and, presumably, efficiency of resource allocation.

In 2006/07, approximately PKR 100 billion was transferred to local governments in Punjab-district governments received PKR 84 billion; TMAs, PKR 12.7 billion; and UCS, PKR 4 billion. In 2002/03, the amount transferred was only PKR 55 billion.

\section{An Assessment of the Devolution System (2002-07)}

The extent of fiscal decentralization remained limited because the districts continued to depend on the province for resources and did not have the power to collect new taxes or the capacity to levy service or user charges. On the expenditure side, both the fixed and growing expenses incurred by staff salaries, wages, and allowances now devolved to the district governments (although staff continued to be provincial servants), not leaving much for maintenance and operation, or for development expenditure.

The functioning of the district governments in the first two years was quite promising, but the conflict between provincial elected representatives and local elected representatives that surfaced after the 2002 provincial and national elections created an adversarial rather than congenial environment. Until then, nazims, under the supervision of army monitoring teams, had been carrying out some useful activities for the welfare of their constituents. However, once the newly elected provincial ministers took office, there was a substantial shift in the power of patronage from them to the district nazims.

This led to a number of amendments, particularly in the Police Ordinance, which diluted the powers of the police command and made the police force once again subservient to the provincial chief minister and Home Department. The proposed Police Rules were not allowed to be finalized, the district services were never established, and the power to recruit, transfer, and post district-level staff remained centralized at the 
provincial level. Gradually, the balance of power, authority, and resources between the provincial and local governments, in practice, moved away from what had been envisaged under the Devolution Plan. The perpetual state of flux, the unease in political relations, the lack of clarity for civil servants working at the district level, and the incomplete transition all adversely affected service delivery.

Wilder (1999) argues that political parties, when in government at the provincial level, tend to view local governments as a competing tier of patronage and, as a result, make no attempt to empower the local government system. If anything, they may even suspend or abolish established local governments when in power. Thus, any elected government that has followed the military regimes that introduced local governments has, at the very least, ignored these local governments and often suspended them altogether. The repetition of these events after the elections of 2008 lends credence to Wilder's hypothesis.

The internal dynamics that arose due to the flawed design of the local government system also took a toll. The integration of rural and urban areas within a common framework led to lopsided decision-making. District headquarters, for example, which were predominantly urban centers, were neglected because the majority of district council members responsible for deciding allocations for development projects hailed from rural areas. The integration had exactly the opposite effect-the fragmentation of development projects in small schemes catering to the narrow needs of local communities without any sense of priority, linkages, or broad coverage.

Ideally, the transfer of resources from urban to rural areas should be a welcome move, but such a transfer in the absence of a district plan and without specifying the goals to be achieved or assessing the cost-benefits of the schemes approved can be counterproductive. The urban-rural integration did not recognize and cater to the needs of the country's growing urbanization. Urban residents within the districts resented what they termed the "tyranny" of the rural majority that deprived them of the services and infrastructure that they felt they deserved.

The indirect election of the district nazim through the UC and tehsil council nazims reinforced the tendency of development schemes toward fragmentation. According to Hasnain (2010), there were 17,000 development schemes in the development portfolio of Punjab's districtstypically neighborhood-specific schemes involving the construction or rehabilitation of small roads or drains. The average size of a typical scheme 
varied between PKR 0.3 million for water and sanitation to PKR 1.5 million for road works. This was not the complete picture because it did not include the block allocation to the UCs and CCB schemes. In order to keep their voters happy, district nazims would have very little choice but to acquiesce to the pressure exerted by the union and tehsil nazims to allocate resources equally.

The difference between "equal" and "equitable" distribution of resources should be understood as the crux of the problem. Under an "equal" distribution scheme, there is no clear relationship between the needs of the community and the intended interventions. Rich and poor communities alike will receive a fixed slice of the pie irrespective of their needs. "Equitable" distribution takes into account the differences in initial endowments and conditions of the intended beneficiaries. Those who are poor, marginalized, live in remote or geographically disadvantaged areas, or cannot earn decent incomes on their own are given higher allocations than those who are better off. Public resources thus supplement the private incomes of the poor and help lift them out of poverty.

It is interesting to note that while the provincial governments took "backwardness" into account when allocating development funds across districts-and the allocations were thus equitable to some extent-the district governments were unable to do the same within their districts due to the inherent design flaw in the system as pointed out earlier. The district nazim would become hostage to blackmailing by members of the district councils, who would either withhold their approval of the budget or threaten to move a vote of no confidence against the nazim. In turn, district nazims were unable to assert their fiduciary responsibilities.

The significant increase in reserved seats for peasants and women was a healthy move under the 2001 Devolution Plan. Greater representation, particularly for women (one third of the total seats) did and could have further changed the quality and composition of expenditures. This might have increased allocations for education, drinking water, health, and sanitation relative to the infrastructure projects generally favored by male representatives. Empirical evidence of this correlation is, however, hard to obtain and, therefore, the assertion remains purely conjectural and is based on casual empiricism based on personal visits to different districts.

The alienation of the powerful District Management Group and provincial civil service cadres caused by the abolition of the posts of 
commissioner, deputy commissioner, and assistant commissioner also proved a stumbling block in the smooth functioning of the new local government system. On one hand, the police force was perceived to have become much stronger because it was removed from the DCO's supervising ambit and made directly accountable to the district nazim. On the other hand, the DCO's executive authority was weakened since his/her magisterial powers were removed although he/she was still expected to perform duties related to law and order, removal of encroachments, and price control, etc. The provincial secretaries from the District Management Group and provincial civil service cadres retained considerable administrative authority over district bureaucrats and used these powers to make elected nazims ineffective. Thus, a tripartite confrontational mode in which provincial ministers and secretaries aligned themselves against the district nazims was responsible for creating most of the practical difficulties that citizens faced in accessing services.

The debate on the local government system has been muddied by Pakistan's historical experience of military governments who, on assuming power, have always taken legal and constitutional steps to strengthen the local government system. Elected political governments at the national and provincial levels have reversed or weakened these systems when they have come to power, ostensibly because a nonrepresentative (i.e., military) government, had co-opted the local governments to legitimize the latter's rule. This suspicion is not far from the truth-General Ayub Khan's "basic democracy" system was indeed used as an electoral college to elect him to political office. General Zia-ul-Haq's decision to hold national elections on a nonparty basis that debarred the country's established political parties was also perceived in the same light. General Musharraf's 2001 Devolution Plan suffered from the same flaw, i.e., elections were held under a nonparty system and district nazims were indirectly elected by an electoral college consisting of UCs and tehsil nazims. The two major political parties held that the nazims elected in this way were intended to become an instrument of state patronage in order to neutralize the popular appeal and support of the traditional parties.

The result of this stop-go arrangement is that the state has only a weak and ineffective presence at citizens' doorsteps, and that a remotely controlled, highly centralized, but still dysfunctional system of governance-particularly in the delivery of essential public services-has been perpetuated. Had the local government system been allowed to evolve and take its natural course, it would have become responsive to citizens' needs, particularly to those of the poor. The abrupt disruptions to 
the system have resulted in a continuing struggle to find a workable system after 64 years of the country's existence. At the heart of this struggle lies the strain between the attempts of provincial and national elected politicians to pre-empt favors and patronage for themselves and decentralized decision-making whereby communities and their local representatives make decisions that maximize their collective welfare.

\section{The Impact of Devolution on Service Delivery}

A social audit survey in 2009/10 of 12,000 households drawn from 21 districts from all four provinces found that 56 percent favored the continuation of the local government system, with high proportions in Punjab and Sindh (Devolution Trust for Community Empowerment, 2011). Only 33.8 percent appeared satisfied with the UCs, but support for and the social acceptability of women's political participation seemed to have improved-60 percent of women union councilors said that people in their constituencies were happy with them. Households' satisfaction levels with regard to various public services varied, but by 2009/10 satisfaction with roads, sewerage and sanitation, garbage disposal, water supply, health, and education had improved, although in percentage terms less than half of the households surveyed expressed satisfaction with public services. Public education showed the highest—a 58 percent satisfaction level.

The Social Policy and Development Centre (SPDC)'s (2007) survey of 12 districts across the four provinces found that the rate of enhancement in literacy and access to water supply and sanitation had increased perceptibly during the post-devolution period. However, there were no indications that devolution had had any impact on health indicators. The devolution process did, however, improve primary school enrolment and literacy in the country. The SPDC observed that, "if this effort at enhancing human capabilities is sustained then it augurs well for achieving more reduction in the incidence of poverty during the coming years. However, the lack of significant change to date in the trend of health indicators, gender equality and regional disparities limits the potential impact of local governments on poverty in the post-devolution scenario."

The SPDC (2007) noted that, while most local functions had been devolved to local governments, a number of issues remained to be resolved concerning the design and speed of implementation of the Devolution Plan. These included the following.

- The need for the intermediate tier, i.e., the TMA, was questioned. 
- A wide range of services was transferred in one go to local governments, which stretched their capacity to the limit. A more gradual strategy could have minimized such challenges.

- Even after the passage of six years, the provincial governments were not fully prepared to devolve power to the local governments.

- Institutional structures to improve accountability and people's participation in the system were either not operational or not performing according to the mandate given by the Local Government Ordinance 2001.

- "State capture" by local elites was an important and persistent challenge. The overwhelming influence of family, biraderi, and tribal ties, and the political maneuvering of union councilors in return for lucrative benefits were quite evident.

- Over 90 percent of the expenditure of local governments was financed by transfers from the provincial governments. The lack of enhancement of local fiscal powers remained a major weakness in the process of fiscal decentralization. The share of local governments in the provincial allocable pool was about 40 percent, but their share in total public expenditure was only 13 percent.

- Primary and secondary education were allocated the largest shares of local governments' current expenditure budgets-in excess of 60 percent. On the development side, a significant portion was allocated for road construction. Health was the most neglected sector, receiving less than 10 percent of the development allocation in most cases.

- While current transfers did not lead to significant fiscal equalization, development transfers were the prime instruments for removing inter-district differentials in access to services over time. However, their role was limited because they were relatively small.

- Resource mobilization at the provincial and local levels remained substantially underexploited. Land revenue accounted for less than 1 percent of agriculture income, while the effective rate of property tax on rental incomes was about 5 percent as opposed to the statutory rate of 20 percent or more.

Hasnain's (2010) analysis of district development priorities in Punjab reveals four stylized facts. First, physical infrastructure, in particular roads, was by far the district governments' highest priority. Second, these infrastructure schemes were small and largely neighborhood-specific. Third, district policymakers appeared to give lower 
priority to operation and maintenance than their provincial counterparts. Finally, provincial interventions in education and health appear to have provided additional incentives for districts to prioritize the physical infrastructure sectors.

The devolution to the districts with respect to primary and secondary education and healthcare, although completed on paper, remained incomplete. Through a variety of measures, including control over finances, the actual delivery of these services remained suboptimal due to strained relations between the provincial and district governments. A more supportive rather than intrusive role on the part of the provincial governments, along with effective monitoring and accountability, would have made a difference for the better. The data shows that 21 percent of Punjab's annual development program allocations for education and health remained with their respective provincial departments. Provincial recurrent expenditures in education and health also grew annually by 48 and 16 percent, respectively, during the post-devolution period.

The Punjab government launched the high-profile Punjab Education Sector Reform Program with a number of interventions targeting primary and middle schools. Funding for the provision of missing facilities was transferred to local governments as tied grants. However, centralized decision-making by the provincial education department and local provincial parliamentary members reduced the availability of funds and compromised prioritization by the district governments. Project implementation under this program was entrusted to the National Logistics Corporation in 2006. The districts, therefore, served mainly as a conduit for funds with no role in identifying, planning, or executing these schemes. The same situation prevailed in the Health Sector Reform Program and the Chief Minister Accelerated Program for Social Development.

\section{Reforming the Local Government System ${ }^{1}$}

The 18 ${ }^{\text {th }}$ Amendment and NFC Award have the potential to overcome some of the structural difficulties and microeconomic distortions that have kept Pakistan a social and economic underachiever. In a multiethnic, multi-linguistic society in which one federating unit is more advanced than the others and enjoys political dominance, it makes sense to

\footnotetext{
${ }^{1}$ Most of these recommendations are drawn from the Report of the National Commission for Government Reforms on reforming the government in Pakistan submitted to the Prime Minister in May 2008 (see Pakistan, National Commission for Government Reforms, 2008).
} 
deconcentrate power and share resources equitably among the provinces. Just as competitive markets allow decentralized decision-making to unleash entrepreneurial energies and economic growth, the devolved units of a state should be able to ensure the judicious and equitable distribution of economic gains, provided that proper checks and balances are put in place.

In the short term, the transition can prove to be destabilizing for macroeconomic management, but there are viable solutions to these problems. The NFC's enhanced transfers to the provinces and the federal government's retained expenditures of the devolved ministries will create pressure on fiscal balances, but this can be resolved by establishing an integrated fiscal framework in which to anchor the federal and provincial budgets. The Council of Common Interests should discuss, debate, and approve this framework and the budgets of the federation and federating units that it presents (Husain, 2011a). The provinces' tax efforts could be encouraged by providing them a matching grant out of the divisible pool. The setting up of the Sindh Revenue Board is a welcome step-in the future, this board should take over all the province's revenue collection functions. The other provinces should set up similar institutions to mobilize their own revenues.

The transfer of legislative, legal, financial, and administrative powers from the federal government to the provinces will necessitate changes in governance structures, systems, and processes. The relationship between the federal, provincial, and local governments has to be redefined. For these changes to be meaningful and make a difference in the delivery of public services, a number of complementary reforms must be undertaken to simplify business processes, revamp human resource management policies, and set up credible and effective accountability mechanisms.

The devolution process should now extend to create a vibrant local government system that clearly demarcates the responsibilities of the provincial and the local governments, embedded in a permanent legal arrangement. The provincial governments should take steps to revive the Provincial Finance Commissions in order to make further allocations to the district governments.

The following analysis identifies specific flaws in the 2001 system that need to be rectified or removed. 
First, as mentioned earlier, district nazims were indirectly elected by the union nazims and were thus beholden to them. Budgetary allocations were often made not on the basis of a district's development priorities but on the union nazim's individual preferences. To avoid this, the distortions created by the indirect, nonparty-based election of district nazims should, therefore, be removed. All political parties should contest elections at each tier, and district nazims should directly contest a districtwide election in which all registered voters should vote. These measures would strengthen political linkages between the district and provincial governments and also free the district nazims of any political obligations to the UC or tehsil nazims.

Second, district nazims should not be vested with the power to make decisions concerning law and order, revenue records, and disaster management since their decisions may be partisan and driven by narrow, parochial considerations. Such functions are best performed by competent, neutral, nonpolitical civil servants who can be trusted by all citizens across the political spectrum. ${ }^{2}$ The weakening of the law enforcement system, tampering with land revenue records, and poor management of national disasters became highly apparent after 2001-DCOs rather than district nazims should be assigned these functions. The Police Order 2002 should be implemented in its unadulterated form with some checks built in, accountabilities clearly established, and the police force removed from the disciplinary rules under the Civil Service Act.

Third, there were no administrative linkages between unions, tehsils, and district governments. Each tier was supposed to work independently of the other; consequently, the lack of coordination among various agencies led to inefficient outcomes. As the head of the local government, the district nazim should have the statutory and legal powers to convene, consult, and direct the tehsil nazim or union nazim to resolve problems and conflicts that are cross-jurisdictional.

Fourth, the accountability of local governments proved perfunctory and almost nonexistent. The provincial governments did not exercise effective control of the departments that were devolved to the districts. The provincial departments retained the power to recruit, transfer, and post staff, and carry out any disciplinary action. The diarchy proved fatal to the effective functioning of the devolved departments. Corruption at the district government level could not be contained due to the inadequate

${ }^{2}$ This will, of course, involve completely restructuring the civil service. See Pakistan, National Commission for Government Reforms (2008) for a blueprint of this restructuring. 
supervisory arrangements put in place by the provincial governments. The $18^{\text {th }}$ Amendment has strengthened the office of the auditor general of Pakistan, which the provincial governments should use to strengthen local governments' monitoring and accountability. The provincial governments should also be responsible for all regulatory functions, including setting standards in health, environment, food, agriculture, and education.

Fifth, as urbanization expands - and about half of Pakistan's population is projected to live in cities by 2025 - it is imperative that the management of metropolitan areas and large cities follow a different model than that of the traditional district government. Public transport, city zoning, commercial, industrial, and residential development, water and sanitation, and solid waste disposal and sewerage have to be managed holistically. In some instances, the metropolitan government could delegate certain responsibilities among various tiers and different providers, but it should retain direct control of planning, regulation, oversight, and monitoring.

Sixth, the separation of the provincial and district service cadres had not been implemented by 2008, although it was envisaged in the law and agreed upon by the provincial governments. Most Grade 1-16 functionaries were, in fact, working in the districts ${ }^{3}$ and their reallocation to the district service would have removed frictions and made a difference to the effectiveness of basic service delivery.

Each province should design a local government system specific to its needs after holding consultations with all stakeholders and political actors to reach a consensus. The flaws of the 2001 system should be addressed while consolidating its strengths. Service delivery under the proposed system can be improved by introducing reforms, particularly in the education and health sectors. This would minimize the system's chances of being overturned in the future and allow it to survive changes in the political regime.

\section{Service Delivery under the 2001 Devolution Plan}

\subsection{Education}

Under the 2001 Devolution Plan, district governments were made responsible for all primary, secondary, and higher secondary education. They could recruit teachers up to a basic pay scale of 16 , while the provincial governments retained authority over staffing-hiring, firing,

\footnotetext{
${ }^{3}$ In Punjab, two thirds of its 1 million employees were employed at the district level.
} 
and transferring-for employees on a basic pay scale of 17 or above. The ban on the wholesale recruitment of teachers by the provincial governments and the authority to relax this ban in individual cases resided with the chief minister. This backdoor tactic meant that the district governments remained wholly dependent on the chief minister's whims. Concessions were granted if the latter belonged to the same political party or was a close political ally of the district nazim. In other cases, nazims were penalized so that posts remained vacant for periods on end. Since many teachers owed their appointments to the provincial or national assembly members, they did not adhere to the discipline enforced by the EDO. Teacher absenteeism was rampant in such cases.

Funding for education came mainly from provincial allocations, but was consumed mostly by salaries and allowances, leaving very little for other expenses. In Sialkot district, as much as 95 percent of budget funds were allocated for salaries and only 5 percent for nonsalary expenses. The physical conditions of schools were found to be poor, with no electricity or water available (Urban Institute, 2006). Teacher training became a popular hobbyhorse for donors to the extent that teachers in Thatta were reported to be spending as many as 17 days on different training courses organized by various donors (Urban Institute, 2006). Yet, despite such heavy investment in teacher training, the outcomes were not very encouraging.

\subsection{Reforming Education Service Delivery 4}

Reforms in the delivery of public services need to be embedded within broader reforms of public administration, institutions, and incentives. Unless the civil services are broadly restructured, business processes reengineered, information technology tools used to monitor performance, and regulatory bodies put in place to oversee executing agencies, sectoral reforms in education and health will have a limited impact.

First, there is a clear need to delineate the responsibility for provision of education among the various tiers of government. The federal government should deal with financing, standards, and regulations in curricula and higher education; the provincial governments should be responsible for college education, and technical and vocational training; while the district governments should take charge of primary, secondary, and high schools.

\footnotetext{
${ }^{4}$ This section draws on Husain (2009).
} 
Second, a district education board consisting of eminent, reputable persons should be established to ensure coordination and uniform standards among public, private, and nonprofit schools. The district education officer would act as the board's secretary and implement its decisions.

Third, as in Sindh and Khyber-Pakhtunkhwa, the management and teaching cadres in the other provinces should also be separate from one another. While selection to the management cadre will be open to teachers with the right aptitude, all teachers should be allowed to progress in their teaching careers without becoming heads/principals/education officers.

Fourth, the teaching cadre should be de-linked from the National Pay Scales. Educational attainment in backward districts will not improve unless remuneration packages are aligned with local market conditions. If, for example, a science teacher in Musakhel has to be paid PKR 15,000 per month to attract her to work in this backward district, she should be given that package. In contrast, if qualified science teachers in Karachi or Lahore are available at a salary of PKR 12,000 per month, then they should be paid that amount. Otherwise the present distortions-teachers appointed in backward districts being transferred to big cities at their present posts under political influence-will persist. Examples abound: Rural schools might have no mathematics teachers but schools in urban Lahore might have six mathematics teachers for only 60 students.

Fifth, all teachers should be appointed from among candidates domiciled in a particular district, through a test conducted by the district Public Service Commission and based on merit alone. These posts should be nontransferable. Other posts for which suitable candidates are not locally available can be filled from outside the district. The powers to recruit, transfer, promote, and impose disciplinary action should all reside with the district education board.

Sixth, school management committees/parent-teacher associations should be empowered to effectively oversee schools' internal management, i.e., ensuring that school infrastructure is in sound shape and that teachers attend class, and resolving any other problems that the schools might face. School management committees would need to be given budgetary resources, but they would be accountable to the district education board for results. Head teachers/principals would be given the appropriate administrative authority to carry out the day-to-day operation of the school and the power to initiate action against recalcitrant teachers. 
Seventh, the district education board should be allocated annual funds to carry out approved infrastructure projects, operation and maintenance, and teacher training in all schools. The provincial government would deliver the training, and also annually assess teachers' competency and students' academic achievements. Funds allocated to the district boards would be audited regularly by the audit department.

Eighth, children from low-income households should be given the option to attend private schools, provided these schools meet prescribed eligibility criteria. These schools could be given per capita grants to cover the tuition costs of students from low-income households. The activities of education foundations in the provinces should be expanded and supported to find other suitable means of fostering public-private partnerships.

Ninth, a decentralized and empowered educational network will function efficiently only if it is continuously monitored. A management information system would help the district boards monitor schools' performance. For example, if the primary school in a locality is producing a constant stream of pupils for enrolment in higher classes, it could be immediately upgraded to an elementary school.

Finally, talented students from poor households and backward districts who secure admission to private schools, professional colleges, business administration institutions, and universities should be awarded scholarships to pursue their education. The eligibility criteria should be announced in advance and advertisements placed inviting applications for scholarships.

\subsection{Health}

The Local Government Ordinance 2001 devolved most health services (basic and rural health, child and maternal health, population welfare, and district and tehsil hospitals) to the district governments, with the exception of large teaching hospitals and medical or dental colleges, which remained under the provincial government's direct control. The fundamental structural discrepancy in the system was that both the provincial Health Department and the elected district nazim retained control over health human resources. The EDO for health was answerable to the elected district nazim for service delivery, but to the provincial government for his/her career advancement. All medical staff report to EDO for health but their postings and transfers were controlled by the provincial Health Department. 
The provincial government was made responsible for the procurement of medical supplies, which resulted in delays, mismatched demand and supply, and the nonavailability of necessary medicines. The district government was not allowed to retain the nominal fees collected by each health facility, even though these were insufficient to cover even a fraction of total costs. Instead, the receipts had to be deposited in the provincial government's account. The system of dual control led to lax supervision and weak accountability, with posts lying vacant and high absenteeism among health staff. These factors limited the impact of devolution on the delivery of health services.

\subsection{Reforming Health Service Delivery ${ }^{5}$}

Health reforms, which are more difficult to enforce because of the medical profession's powerful influence, have to follow multiple tracks. These are described below.

First, each provincial government should establish a separate health management cadre to provide duly trained and experienced managers for hospitals and institutions and for development projects and the district/provincial health administration. The selected personnel would fill all administrative positions at the tehsil and district levels in teaching and specialized health cadre facilities, and act as deputy district officers and EDOs for health and other management positions in the provincial health departments. All cadre personnel should be recruited through an open, transparent, merit-based system based on their satisfactory completion of mandatory training at different levels. The management cadre would be different from the clinical and teaching cadre, and have its own career progression path. Recruitment rules should allow both internal and external recruitment. However, all senior management positions should be advertised and selection based on merit.

Second, the office of the provincial director general for health should be made responsible for developing norms and standards for establishing policy, operational guidelines, and regulatory frameworks for fostering public-private partnerships. An independent, autonomous drug regulatory authority at the federal level should be set up as a priority. Health regulatory authorities should operate at the provincial level to implement these frameworks and to mainstream the role of the private sector into the delivery of healthcare, the services of bona fide NGOs into

\footnotetext{
${ }^{5}$ For a comprehensive review of health systems and reforms, see Nishtar (2010).
} 
the national development process, and to foster public, not-for-profit relationships at an overarching level. The licensing standards prescribed by these authorities should be strictly enforced to prevent unqualified practitioners from practicing medicine.

Third, the health sector's inter-sectoral linkages with social welfare, water and sanitation, and population need strengthening. A district-level coordination mechanism to synergize the roles and contributions of all the actors in the health sector should be established in the form of district health boards, comprising members drawn from the various sectors. National vertical health programs should also be integrated through this district coordination mechanism.

Each district health board would consist of prominent, reputable citizens from the public and private sectors. The EDO for health would be the board secretary and assigned operational responsibilities, and an eminent member either from the public or private sector would be chosen to chair the board. As an oversight body, the board would plan, guide, oversee, and coordinate the delivery of health services within the district in line with local needs, albeit within the ambit of the national health policy framework.

Fourth, to overcome the problem of teaching faculty not paying sufficient attention to their patients, the annual performance reports of members belonging to the teaching cadre should evaluate the proportion of time given to patient care (daily rounds/ward visits/OPD/cases attended); time spent in student training (lectures, thesis supervision, etc.); and contributions to medical research (number of publications in peerreviewed journals rather than local hospital journals). Promotion criteria should be revised; teaching staff should be statutorily bound to contribute both to quality patient care as well as research.

Fifth, the private sector could be allowed to provide medical and vocational training to produce nurses, paramedics, etc., subject to properly regulated compliance concerning the quality of output. Private investors could be given incentives to set up institutions complying with minimum prescribed standards. In areas where the government has a limited absorptive capacity, it could choose to subsidize the private sector in training human resources. The federal government should prepare a fiveto-ten-year health human resources plan that could be implemented by the provinces in collaboration with the private sector. 
Sixth, health professionals' pay scales should be delinked from the national pay scales. The Pay and Pension Commission (2010) has proposed a separate pay scale for health professionals. This scale should be introduced along with performance-based increments in all the provinces.

\section{Conclusion}

The $18^{\text {th }}$ Amendment to the Constitution, the NFC Award of 2010, and the implementation commission headed by Senator Raza Rabbani have largely helped clarify the structure, roles, and responsibilities of the federal and provincial governments. The missing link is the devolution of responsibilities to local governments-the cornerstone of public service delivery at the grassroots level. This article has recommended measures to fill this gap, based on extensive consultations carried out in 2006-08 with a large number of stakeholders across the country. The creation of a district civil service structure in addition to the existing federal and provincial services, for example, would help improve the effectiveness of service delivery at the local level.

These structural reforms will not be successful, however, unless complementary reforms to simplify business processes, revamp human resource management policies, and establish credible and effective accountability mechanisms are put in place. Specific recommendations in each of these areas have been developed after reaching a broad consensus (see Pakistan, National Commission for Government Reforms, 2008; Pay and Pension Commission, 2010). If the agreed reforms are systematically discussed in an informed manner and subsequently adopted, they will help immensely in moving forward in the right direction. Given that the implementation period required is quite long, it would be advisable to phase in these reforms by first implementing those that have the highest or immediate payoff.

This analytical survey of the 2001 local government reforms shows that the provinces need to retain a number of the reforms' strengths and build them into the new local government system. Despite the short trial period, it is apparent that devolution, decentralization, and deconcentration along with local-level elections do spread benefits more widely, improving the efficiency of service delivery and access to local representatives. Limited micro-level studies have shown that nonelite and marginalized groups have participated in the post-reform provision of services. 
However, the devolution system also has many weaknesses that have to be removed or neutralized through appropriate policy and institutional changes. The abolition of a neutral, nonpolitical civil service responsible for law and order, revenue records, and disaster management has weakened the writ of the state at the grassroots level and biased the administration of justice, increased discretionary favors, and led to lax enforcement of laws. The need for reforms in the service delivery of education and health in light of the experience gained since 2001 is well established. Previously underprovided villages received services but the spatial and social inequality of provision between villages and social groups have also been reinforced. Patron-client factions organized by influential village members has determined the winners and losers of postreform provision. The proposed reforms would go a long way in overcoming the distortions and deficiencies of the devolution system. 


\section{References}

Asian Development Bank, Department for International Development, and World Bank. (2004, May). Devolution in Pakistan: An assessment and recommendations for action. Islamabad, Pakistan: Authors.

Bardhan, P., \& Mookherjee, D. (Eds.) (2007). Decentralization and local governance in developing countries: A comparative perspective. New Delhi, India: Oxford University Press.

Cheema, A., \& Mohmand, S. K. (2006). Bringing electoral politics to the doorstep: Who gains, who loses? (Mimeo). Lahore, Pakistan: Lahore University of Management Sciences.

Cheema, A., Khwaja, A., \& Qadir, A. (2005). Decentralization in Pakistan: Context, content and causes (Research Working Paper No. 05-034). Cambridge, MA: Harvard University, Kennedy School of Government.

Devolution Trust for Community Empowerment. (2011). Social audit of governance and delivery of public services: National report 2009-10. Islamabad, Pakistan: Author.

Hasnain, Z. (2010). Devolution, accountability and service delivery in Pakistan. Pakistan Development Review, 49(2), 129-152.

Husain, I. (2009, October 5). Governance reforms in education. Dawn.

Husain, I. (2011a, July 25). Maximizing benefits from the local government system. The News.

Husain, I. (2011b, July). Models of local democracy within a federal system: The experience of Pakistan. Paper presented at the Commonwealth Conference, Karachi, Pakistan.

Jamal, H., Khan, A. J., Toor, I. A., \& Amir, N. (2003). Mapping the spatial deprivation of Pakistan. Pakistan Development Review, 42(2), 91-111.

Manning, N., Porter, D., Charlton, J., Cyan, M., \& Hasnain, Z. (2003). Devolution in Pakistan: Preparing for service delivery improvements. Islamabad, Pakistan: World Bank. 
Nishtar, S. (2010). Choking pipes: Reforming Pakistan's mixed health system. Karachi, Pakistan: Oxford University Press.

Pakistan, National Commission for Government Reforms. (2008). Report of the National Commission for Government Reforms on reforming the government in Pakistan (Vols. 1-2). Islamabad, Pakistan: Author.

Social Policy and Development Centre. (2007). Social Development in Pakistan: Devolution and human development in Pakistan (Annual Review). Karachi, Pakistan: Author.

Urban Institute. (2006). Assessing the impact of devolution on healthcare and education in Pakistan. Washington, DC, Author.

Wilder, A. R. (1999). The Pakistani voter: Electoral politics and voting behavior in the Punjab. Karachi, Pakistan: Oxford University Press.

World Bank. (2004). World development report 2004: Making services work for poor people. Washington, DC: Oxford University Press.

World Bank. (2006). World development report 2006: Equity and development. Washington, DC: Oxford University Press. 